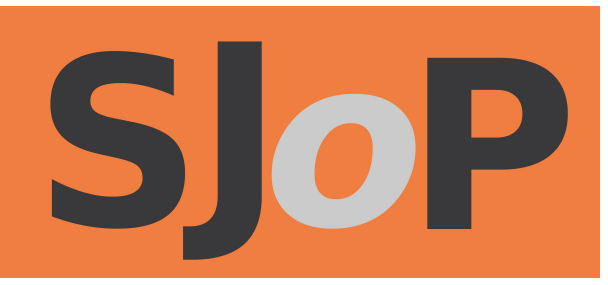

CD review: Dichroic light: music for soloists, chamber ensembles and electronic, by Matthew Whiteside

\title{
DREW HAMMOND
}

The Scottish Journal of Performance

Volume 3, Issue 1; June 2016

ISSN: 2054-1953 (Print) / ISSN: 2054-1961 (Online)

Publication details: http://www.scottishjournalofperformance.org

To cite this article: Hammond, D., 2016. CD review: Dichroic light: music for soloists, chamber ensembles and electronic, by Matthew Whiteside. Scottish Journal of Performance, 3(1): pp.139-141.

To link to this article: http://dx.doi.org/10.14439/sjop.2016.0301.13 


\title{
CD review: Dichroic light: music for soloists, chamber ensembles and electronic, by Matthew Whiteside
}

\author{
DREW HAMMOND
}

DOI: $10.14439 /$ sjop.2016.0301.13

Publication date: 29 June 2016

Dichroic light, by Matthew Whiteside. IMBT Music, 2015; Barcode:888295263849 (£14.89)

The title, Dichroic light, implies a filtering of the concrete and the whole into an ethereal, alternate, damaged reality. And there you have it: many of these tracks live up to that title. The sonorous personalities of wood, reed and string emerge at times aggrandized, and alternately feeble and limp, and at other times still, simple and complete. The music falls broadly under the rubric of 'live electronics', and I think by and large captures the worthier aspects of the field. What we have here utilises the ineffable complexities of human performance, explicitly transmuted by the acousmatic veil of audio processing, to enable, at its best, something indeed worth hearing. Apart from a few things that belie a fully formed artistic statement, this debut collection forms a strong resumé for Matthew Whiteside, a young composer not many years out of formal education. There is an emerging confidence here, and while some things fail to captivate, the brighter spots light the path to a promising future. Matthew casts a wide collaborative net, working with the new music ensemble, Red Note, as well as a number of soloists, and two string quartets. It must be said that success here can be put down to their efforts as well, with some commanding performances from the players. The work with soloists deserves particular attention, as it tends to outshine some of the ensemble tracks. 
Starting us off, 'Ulation' is one of the highlights of this collection. Emma Lloyd's steady, swooping performance on the viola is threaded between soft, sine wave-heavy drones, and bright, resonant, glitch-y textures. The formal shapes and varied surface texture play on listener expectations and make for an enveloping six minutes. Emma returns in track three on the viola d'amore, which establishes a more contemplative character. In this 'Solo for viola d'amore and electronics' Matthew demonstrates for us an encouraging subtlety and restraint in his processing of the audio. The resonance of the cello becomes the focal point in the threemovement centrepiece that lends its name to the album. Abby Hayward plays well, and presumably sings well on the third movement. This one to my mind has its limitations, notwithstanding some exceptional moments. The opening can't but bring to mind Gérard Grisey's 1975 exploration of the overtone series, 'Partiels', transposed to E flat, which I take to be a nod by Matthew to his stately predecessor. The work is taken in a much different direction from here, however, and we get a glimpse of the composer's ability to carve out delicious, sinuous melodic phrases, although I am not convinced that all of the elongated reverb really adds much to the effect. The third movement, while well done, runs the risk of edging into Hans Zimmer-esque cinematic exoticism (think of Russell Crowe wandering through wheat fields in Roman body armour). My reservations can be mostly set aside for 'Three Pieces for Bass Clarinet and Electronics' with the impressive clarinettist, Joanna Nicholson. The first piece affects a delicate rippling that captivates from the start, but the real treat is the third piece, which unites the bass clarinet's extended timbral vocabulary with well-judged layering and delay. This is one I'll go back to.

The ensemble tracks-excellently played by Red Note, The Robinson Panoramic Quartet, and the Aurea Quartet-seem at times like clippings from another book. The exception is 'Quartet No. 3', which works the string quartet with 
electronics into earnest, eager and expressive textures. But by the time we get to it, I'm already thinking back to those delicately sculpted moments that show Matthew's flair for working with the expressive freedom and flexibility of the solo performer.

\section{About the review author}

DREW HAMMOND is a composer and musician based in Glasgow, Scotland. Born in Central Kentucky, he studied music at Guilford College in North Carolina and spent a large chunk of the 1990s touring in bands. Around the turn of the century, he moved to Glasgow, Scotland to study composition with Bill Sweeney. Since then he has gained a PhD in composition and has taught numerous music subjects at the University of Glasgow and the Royal Conservatoire of Scotland. He writes music for a variety of instrumental and electronic forces. 